\title{
SIZE DISTRIBUTION OF ATMOSPHERIC PARTICULATE IONIC SPECIES AT A COASTAL SITE IN PORTUGAL
}

\author{
Célia Alves*, Casimiro Pio, Eduarda Campos and Patrícia Barbedo \\ Departamento de Ambiente e Ordenamento, Centro de Estudos do Ambiente e do Mar, Universidade de Aveiro, \\ Campus de Santiago, 3810-193 Aveiro, Portugal
}

Recebido em 18/1/07; aceito em 27/4/07; publicado na web em 25/10/07

\begin{abstract}
SIZE DISTRIBUTION OF ATMOSPHERIC PARTICULATE IONIC SPECIES AT A COASTAL SITE IN PORTUGAL. A Berner impactor was used to collect size-differentiated aerosol samples from March to August 2003 in the city of Aveiro, on the Portuguese west coast. The samples were analysed for the main water-soluble ion species. The average concentration of sulphate, nitrate, chloride and ammonium was $6.38,3.09,1.67$ and $1.27 \mu \mathrm{g} \mathrm{m}^{-3}$, respectively. The results show that $\mathrm{SO}_{4}{ }^{2-}$ and $\mathrm{NH}_{4}{ }^{+}$were consistently present in the fine fraction $<1 \mu \mathrm{m}$, which represents, on average, 72 and $89 \%$ of their total atmospheric concentrations, respectively. The $\mathrm{NO}_{3}$-particles were concentrated in the coarse size. Chloride presented the characteristic coarse mode for marine aerosols. During some spring/summer events, an ammonium surplus was observed $\left(\mathrm{NH}_{4}{ }^{+} / \mathrm{SO}_{4}{ }^{2-}\right.$ molar ratios $\left.>2\right)$, possibly due to greater availability of ammonia coming from agricultural activities or from the neighbouring chemical industrial complex. During the remaining periods, the aerosol was found to be somewhat acidic and predominantly in the form of ammonium bisulphate $\left(\mathrm{NH}_{4}^{+} / \mathrm{SO}_{4}{ }^{2-}\right.$ molar ratios $=$ 0.5-1.25). Samples collected under a major or exclusive influence of maritime air masses were essentially constituted by coarse particles with enrichment in sea salt, while for air masses of continental origin the contribution of water-soluble ionic species in the fine mode was more pronounced.
\end{abstract}

Keywords: water soluble ions; atmospheric aerosol; size distribution.

\section{INTRODUCTION}

Aerosols are present throughout the boundary layer, at number concentrations depending upon factors such as location, atmospheric conditions, annual and diurnal cycles and presence of local sources. The highest concentrations are usually found in urban areas ${ }^{1}$, reaching up to $10^{8}$ and $10^{9}$ particles per $\mathrm{cm}^{3}$. While natural aerosols such as dust, sea salt or volcanic particles have always been present in the atmosphere, aerosols caused by human activities have augmented noticeably, above all since 1950, as an outcome of fossil fuel combustions. Inorganic species normally represent $25-50 \%$ of the aerosol mass, with sulphates $\left(\mathrm{SO}_{4}^{2-}\right)$, ammonium $\left(\mathrm{NH}_{4}^{+}\right)$and nitrates $\left(\mathrm{NO}_{3}^{-}\right)$as major components ${ }^{2}$.

Sulphate is emitted into the atmosphere from a variety of sources. Over continents, fossil fuel combustion and volcanoes contribute to significant emissions of $\mathrm{SO}_{2}$, one of the precursors of sulphate aerosols. Over oceans, phytoplankton releases dimethyl sulphide (DMS), which rapidly oxidises to $\mathrm{SO}_{2}$. Most $\mathrm{SO}_{2}$ is converted in sulphate either in the gas phase or in the aqueous phase. The reaction products of $\mathrm{SO}_{2}$ in the atmosphere are non-volatile and will not return to the gas-phase once formed. The speciation of the particulate sulphates as sulphuric acid, ammonium bisulphate, ammonium sulphate, or some combination of the above, is principally determined by the amount of ambient ammonia available to neutralise the acid sulphate species. Sulphate aerosols promote the creation of cloud condensation nuclei (CCN). Thus, cloudiness can be enhanced, causing more solar radiation to be reflected back into space. This negative forcing effect acts to restrain the signal of global warming. Because they are nonabsorptive in the visible region of the electromagnetic spectrum, they provide the most significant anthropogenic cooling contribution to global direct radiative forcing. The calculated global mean radiative forcing ranges from -0.26 to

*e-mail: celia.alves@ua.pt
$-0.82 \mathrm{~W} \mathrm{~m}^{-2}$, although most lie in the -0.26 to $-0.4 \mathrm{~W} \mathrm{~m}^{-2}$ range $^{3-8}$. In addition, it is known that sulphate aerosols react with water to produce acid rain, and if they arrive at the stratosphere, may, under certain conditions, contribute to the destruction of the ozone layer ${ }^{9}$.

Gaseous ammonia is the third most abundant nitrogen compound and the most abundant alkaline trace gas in the atmosphere. As the principal neutralising agent for atmospheric acids, ammonia plays an important role in aerosol formation. It is thought to be a major influence on regional air quality, atmospheric visibility, and acid deposition. Although the main source of atmospheric ammonia is agriculture, other sources comprise industries, landfills, household products, biomass burning, motor vehicles, and wild animals ${ }^{10}$. The main sink for ammonia in the atmosphere is the heterogeneous reaction with sulphuric acid, yielding ammonium sulphate $\left[\left(\mathrm{NH}_{4}\right)_{2} \mathrm{SO}_{4}\right]$ and ammonium bisulphate $\left[\mathrm{NH}_{4} \mathrm{HSO}_{4}\right]$ salts. Reactions with nitric and hydrochloric acids form ammonium nitrate $\left(\mathrm{NH}_{4} \mathrm{NO}_{3}\right)$ and ammonium chloride $\left(\mathrm{NH}_{4} \mathrm{Cl}\right)$ salts ${ }^{11}$. These $\mathrm{NH}_{4}^{+}$aerosols affect Earth's radiative balance, both directly by scattering incoming radiation and indirectly by acting as $\mathrm{CCN}$. They also contribute to the long-range transport of acidic pollutants, because the atmospheric lifetime of ammonia is short $(<24 \mathrm{~h})$, while that of $\mathrm{NH}_{4}{ }^{+}$salts is on the order of a few days ${ }^{12}$. Long-range transport can result in deposition of the $\mathrm{NH}_{4}^{+}$ salts faraway from the emission sources. After deposition, $\mathrm{NH}_{4}^{+}$ aerosols can contribute to soil acidification, forest decline, and eutrophication of waterways ${ }^{11,13}$.

Nitrate aerosols are formed by reactions involving atmospheric nitric acid vapour. This acid is produced in the atmosphere as an additional reaction product of $\mathrm{NO}_{2}$, which may have both an anthropogenic (fossil fuel combustion) or natural origin (soil and lighting). During the daytime, $\mathrm{NO}_{2}$ oxidation takes place by reaction with the hydroxyl radical. At night, $\mathrm{NO}_{2}$ can react to form nitric acid by pathways relied on formation of the nitrate radical, $\mathrm{NO}_{3}$, pursued by production of $\mathrm{N}_{2} \mathrm{O}_{5}$, which then can hydrolyse to originate nitric 
acid. The nitrate radical can also react with some organic constituents to produce $\mathrm{HNO}_{3}$. Nitric acid reacts with $\mathrm{NH}_{3}$ to form ammonium nitrate. Since ammonium nitrate is a solid or liquid phase species, gas-to-particle conversion occurs at this point. The value of the equilibrium dissociation constant for ammonium nitrate is very sensitive to temperature and humidity, with more ammonium nitrate formation from the same quantity of ammonia and nitric acid vapour expected at low temperature and at high relative humidity. While intense photochemical smog episodes greatly favour rapid nitric acid vapour production, such photochemical smog episodes often happen on days with very high temperatures that do not necessarily help ammonium nitrate production form that nitric acid vapour. Instead at high temperatures the nitric acid vapour may well stay in the gas phase where it is available for relatively rapid deletion by dry deposition at the ground. A second frequent path for nitrate aerosol formation involves nitric acid attach on the $\mathrm{NaCl}$ in sea salt particles to generate $\mathrm{NaNO}_{3}$ aerosol and to release gaseous chloride species to the atmosphere. Source for chloride in aerosols and precipitation is among the most trouble-free for any of the major ions, being derived almost entirely from the sea surface ${ }^{14}$. Very little chloride is found in continental dust, except for arid and semi-arid climates where halite $(\mathrm{NaCl})$ can be detected in the soils. Very discrepant estimates of the radiative forcing due to anthropogenic nitrate aerosol have been presented $^{7,8,15}$, ranging from -0.02 to $-0.22 \mathrm{~W} \mathrm{~m}^{-2}$. These studies highlight the problems in measuring the concentrations and size distributions of nitrate, which is a semi-volatile substance.

Understanding the formation, transport and removal of atmospheric aerosols requires detailed information on their size and chemical characteristics. Relatively few investigations have dealt with the inorganic chemical composition of size-distributed aerosols. Many of the researches to data have focused on the characterisation of the bulk particulate matter (total suspended particulate matter, TSP; particulate matter $<10 \mu \mathrm{m}, \mathrm{PM}_{10}$; or particulate matter $<2.5 \mu \mathrm{m}, \mathrm{PM}_{2.5}$ ) and are short-termed. This work presents data obtained during a half-year period about the concentrations and size distributions of the major inorganic ions in atmospheric aerosols under slightly polluted urban conditions in a costal Portuguese city.

\section{EXPERIMENTAL}

Sample collection, between March and August 2003, was performed on the roof of a building (about $15 \mathrm{~m}$ above the ground level) of the University of Aveiro ( $\left.40^{\circ} 38^{`} \mathrm{~N}, 8^{\circ} 39^{\prime} \mathrm{W}\right), 7 \mathrm{~km}$ from the coast. The campus of the University of Aveiro occupies an area of approximately 92 ha and is surrounded by residential areas, some agricultural and forest spots, and the extensive estuary of the river Vouga. An industrial complex, which includes the production of nitric acid, aniline, nitrobenzene and chlorate compounds from rock salt, is located $10 \mathrm{~km}$ to the North of Aveiro. The town, located about $70 \mathrm{~km}$ south of Oporto and $265 \mathrm{~km}$ north of Lisbon, has a population of approximately 60,000 inhabitants. The University of Aveiro has a meteorological station that supplies information about wind direction and speed, temperature, relative humidity, precipitation and solar radiation. The region is characterised by moderate temperatures, having an annual precipitation of approximately $1000 \mathrm{~mm}$. Rainfall occurs principally between late fall and early spring and is associated with maritime air mass transport from the south sector. During the dry warm season the coastal area is influenced by mesoscale sea breeze circulation with strong winds from the Northwest ${ }^{16}$.

Aerosol was collected on aluminium foils by using a 9-stage Berner-type low-pressure impactor without inlet. With a sampling rate of $30.8 \mathrm{~L} \mathrm{~min}^{-1}$, the aerodynamic cut-off diameters of the stages were $0.0625,0.125,0.250,0.50,1.0,2.0,4.0,8.0$ and $16 \mu \mathrm{m}$. The duration of the sampling was about $72 \mathrm{~h}$, which corresponds to an air volume of $133 \mathrm{~m}^{3}$. Exposed filters were used for the determination of the major water soluble inorganic ions. The filters were extracted with distilled deionised water by ultrasonic and mechanical shaking and filtered through a pre-washed Whatman 42 filter. The anionic content $\left(\mathrm{Cl}^{-}, \mathrm{NO}_{3}^{-}\right.$and $\left.\mathrm{SO}_{4}^{2-}\right)$ of the aqueous extract was analysed on a Dionex-100 ion chromatograph, equipped with an analytical column IonPac AS4, a guard column AG4, and an AMMSII micro-membrane suppressor. An auto-sampling injector (Gilson 231) was used to introduce $200 \mu \mathrm{L}$ of sample into the eluant $\left(2.8 \mathrm{mM} \mathrm{NaHCO}_{3} / 2.25\right.$ $\mathrm{mM} \mathrm{Na}_{2} \mathrm{CO}_{3}$ ) maintained at $2 \mathrm{~mL} \mathrm{~min}^{-1}$. The extract was also analysed for $\mathrm{NH}_{4}^{+}$by indophenol-blue spectrophotometry ${ }^{17}$. Blank aluminium foil was also extracted for each analysis and the blank masses were subtracted to values found in samples.

\section{RESULTS AND DISCUSSION}

The particulate matter concentrations observed at Aveiro $\left(30.7 \pm 12.7 \mu \mathrm{g} \mathrm{m}^{-3}\right)$ are higher than background levels in continental Europe. Background annual average concentrations for continental Europe are $7.0 \pm 4.1$ and $4.8 \pm 2.4 \mu \mathrm{g} \mathrm{m}^{-3}$ for $\mathrm{PM}_{10}$ and $\mathrm{PM}_{2.5}$, respectively ${ }^{18}$. The periods with low concentrations coincided with days with synoptic systems of low pressure associated with rain (Figure 1). It seems that most of the regional influence affecting chlorine loadings was due to naturally occurring events, such as strong sea breeze winds. In general, $\mathrm{Cl}^{-}$peak concentrations are associated with periods of strong winds, which promote the bursting of air bubbles at the ocean surface. For $\mathrm{NO}_{3}^{-}, \mathrm{SO}_{4}{ }^{2-}$ and $\mathrm{NH}_{4}^{+}$it was not observed any specific dependence on wind speed. During rainy events, the concentrations of PM tend to be lower, because the particle soluble fraction is washed out before sampling and due to wet deposition processes ${ }^{19}$. About $50 \%$ of samples presented an unimodal coarsesized distribution (Figure 2). The other half of the samples revealed bimodal size distributions, peaking between 0.25-1.0 $\mu \mathrm{m}$ (accumulation mode) and between 2-8 $\mu \mathrm{m}$ (coarse mode).

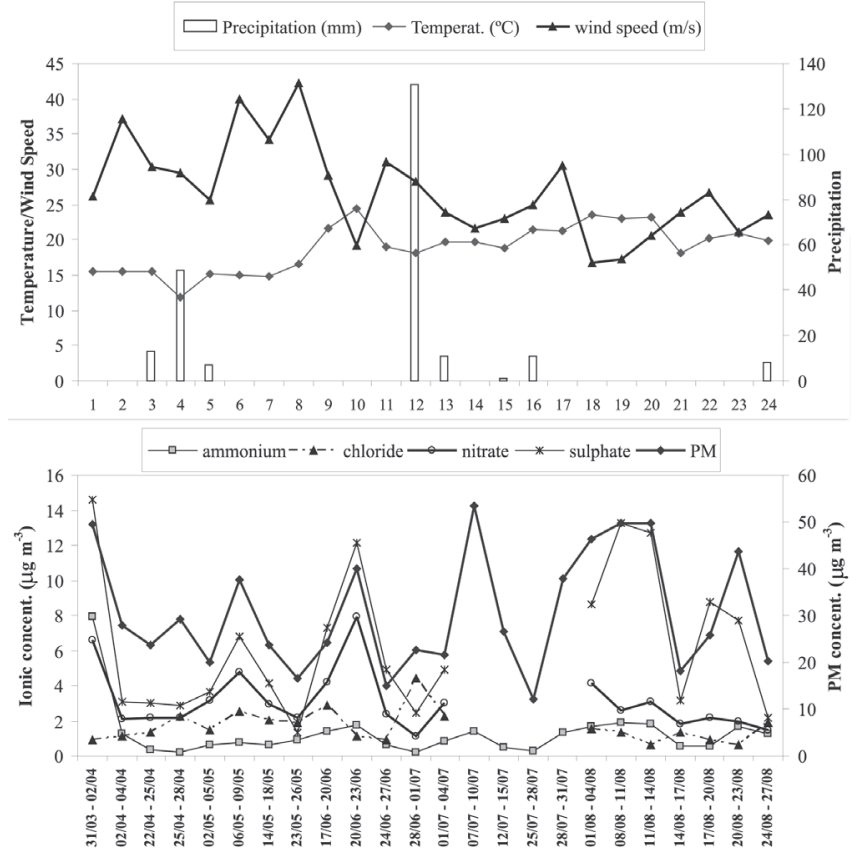

Figure 1. Temporal variation of meteorological parameters, particulate matter and ionic species 

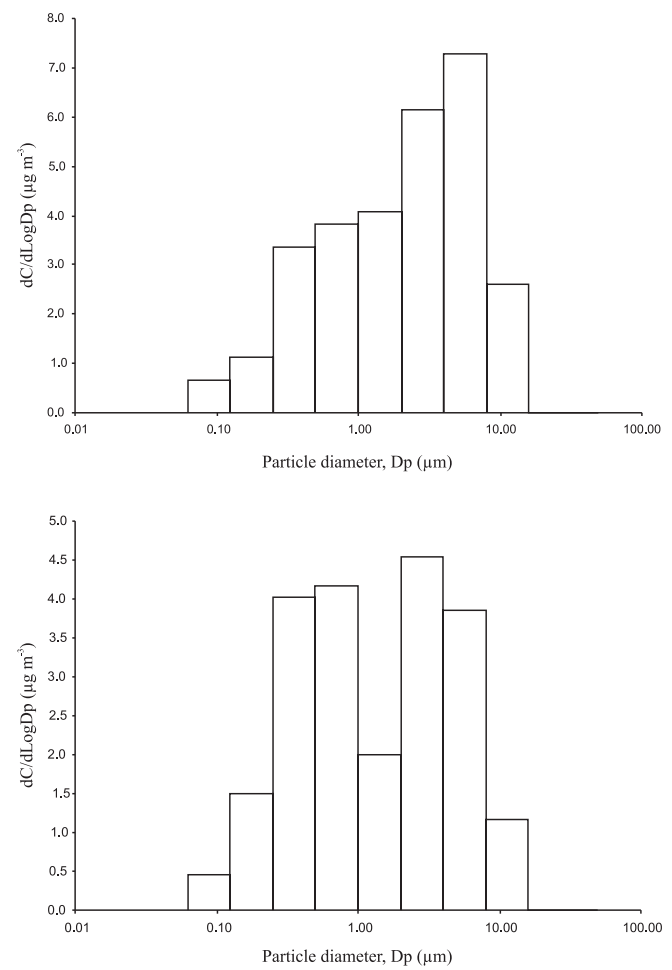

Figure 2. Typical size segregated distributions of particulate matter

Isobaric $24 \mathrm{~h}$ backward trajectories ending at Aveiro were determined for every $6 \mathrm{~h}$ using the HYSPLIT (HYbrid SingleParticle Lagrangian Integrated Trajectory) model. Briefly, the dispersion of a pollutant is calculated by assuming either puff or particle dispersion. In the puff model, puffs expand until they surpass the size of the meteorological grid cell (either horizontally or vertically) and then divide into numerous new puffs, each with its contribute to the pollutant mass. In the particle model, a preset number of initial particles are advected about the model domain by the mean wind field and a turbulent component. The model's default arrangement assumes a puff distribution in the horizontal and particle dispersion in the vertical direction. In this way, the larger accuracy of the vertical dispersion parameterisation of the particle model is merged with the benefit of having an ever expanding number of particles represent the pollutant distribution.

During the sampling period, Aveiro was under two main influences (Figure 3): transportation of air pollutants by the continental outflow and maritime air masses from the Atlantic. It was verified that samples collected under a major or exclusive influence of maritime air masses were essentially constituted by coarse particles with enrichment in sea salt (Figure 4). When air masses were mostly of continental origin the contribution of water-soluble ionic species was even more pronounced, especially for the finest fractions of aerosols.

The average concentrations of ionic species for the aerosol samples in Aveiro and in different locations over the world are presented in Table 1. It could be seen that levels in the Portuguese city are lower than those in various Asiatic sites and are comparable with values registered in other European locations.

On average, $\mathrm{SO}_{4}^{2-}$ had the highest concentration, followed by $\mathrm{NO}_{3}^{-}, \mathrm{Cl}^{-}$and $\mathrm{NH}_{4}^{+}$. A different pattern, in particular with higher concentrations for $\mathrm{NO}_{3}^{-}$and $\mathrm{NH}_{4}^{+}$, would be expected for cold weather, due to the large availability of precursor $\mathrm{NO}_{\mathrm{x}}$ in the winter resulting from additional emissions from domestic heating not operating in summer. Moreover, the reaction between gas-phase

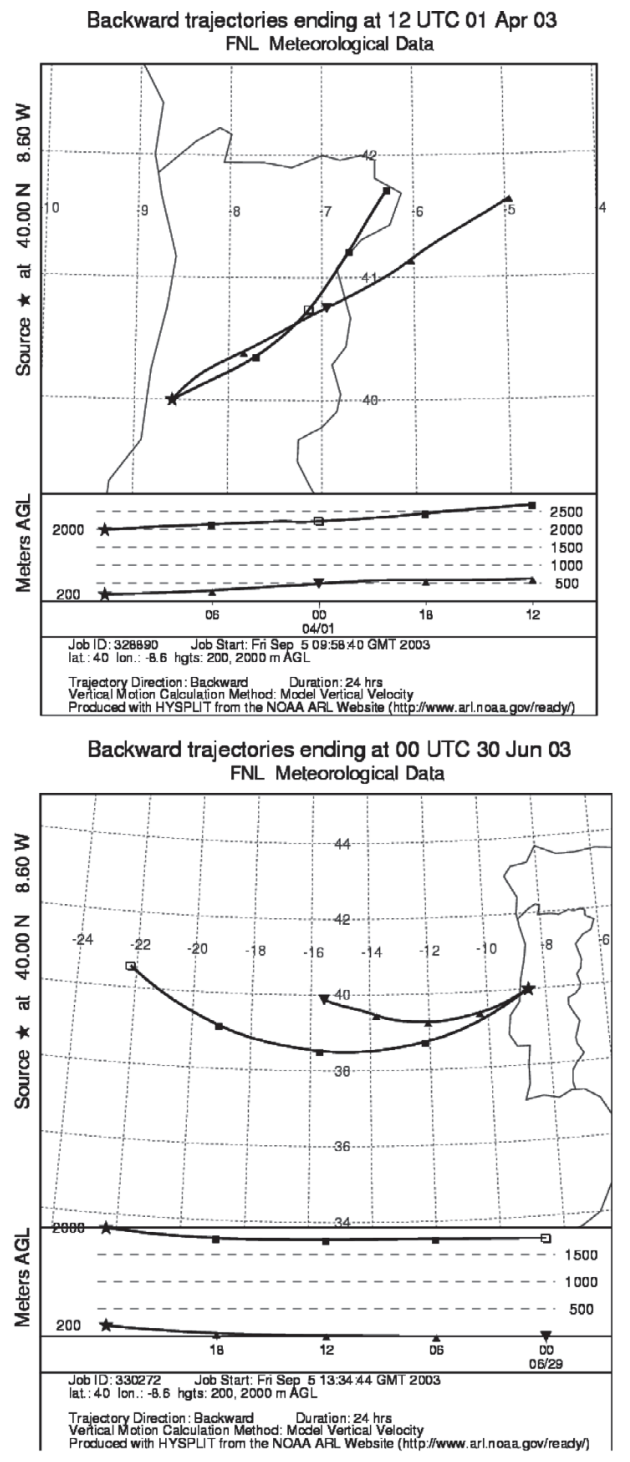

Figure 3. Typical backward trajectories to Aveiro at 200 and $2000 \mathrm{~m}$ above ground, showing the predominant air masses

ammonia and nitric acid to form particulate-phase ammonium nitrate is favoured by the low ambient temperature of winter ${ }^{32}$. The results show that $\mathrm{SO}_{4}{ }^{2-}$ and $\mathrm{NH}_{4}^{+}$are consistently present in the fine fraction $<1 \mu \mathrm{m}$, which represents, on average, 72 and $89 \%$ of their total atmospheric concentrations, respectively. Submicron $\mathrm{SO}_{4}$ particles consist primarily of non-sea-salt sulphate formed by gasto-particle conversion of the photo-oxidation products of sulphurcontaining gases ${ }^{19}$. It should be noted, however, that the occurrence of $\mathrm{SO}_{4}^{2-}$ in the 0.7-1.6 $\mu \mathrm{m}$ cannot be explained by primary emission, gas-phase nucleation or condensation, such as in the case of smaller diameters. Growth of the condensation mode particles and/or evaporation of large droplets may form these aerosols. A possible mechanism could be aqueous-phase oxidation of $\mathrm{SO}_{2}$ in cloud droplets ${ }^{31}$. In Aveiro, an enhancement of $\mathrm{SO}_{4}{ }^{2-}$ concentrations corresponding to the coarse region was registered simultaneously with a strong maritime influence of air masses (Figure 4). These levels may originate from both sea-salt and soil particles ${ }^{31}$. Because the sampling site was in a coastal area, contribution of sea-salt sulphate likely represented the most important contribution. Fine particulate ammonium originates from ammonia vapour, which reacts or condenses on an acidic particle surface and accumulates 
Table 1. Concentration of particulate matter and water-soluble ions at different locations over the world (units: $\mu \mathrm{g} \mathrm{m}^{-3}$ )

\begin{tabular}{|c|c|c|c|c|c|c|}
\hline Location & Particulate Matter Concentration & $\mathrm{NH}_{4}^{+}$ & $\mathrm{Cl}^{-}$ & $\mathrm{NO}_{3}^{-}$ & $\mathrm{SO}_{4}{ }^{2-}$ & Ref. \\
\hline Aveiro, Portugal & $\mathrm{PM}<16 \mu \mathrm{m}=30.7$ & 1.27 & 1.67 & 3.09 & 6.38 & This study \\
\hline Shanghai, China & $\mathrm{TSP}=230.5$ & 5.68 & 8.06 & 14.19 & 17.93 & 20 \\
\hline Fukue Island, Japan & - & 1.57 & 0.07 & 0.56 & 4.80 & 21 \\
\hline Marseilles (urban), France & $\mathrm{TSP}=35.1$ & 1.40 & 0.35 & 1.40 & 4.91 & 22 \\
\hline Dupail (forest), France & $\mathrm{TSP}=21.9$ & 1.53 & 0.004 & 0.88 & 3.72 & 22 \\
\hline Guiyang, SW China & & & & & & 23 \\
\hline Rainy & $\mathrm{TSP}=134.3$ & 3.72 & 0.92 & 3.09 & 22.02 & \\
\hline Not rainy & $\mathrm{TSP}=237.2$ & 5.83 & 2.01 & 9.60 & 29.18 & \\
\hline Hanoi (urban), Vietnam & $\mathrm{PM}_{10}=37.8$ & 0.146 & 0.340 & 0.287 & 2.569 & 24 \\
\hline Lucman (rural), Vietnam & $\mathrm{PM}_{10}=37.8$ & 0.204 & 0.264 & 0.150 & 1.614 & 24 \\
\hline Kaohsiung City, Taiwan & $\mathrm{PM}_{25}^{10}=68.0$ & 7.89 & 2.08 & 11.31 & 14.34 & 25 \\
\hline \multirow[t]{2}{*}{ Tokchok Island, Yellow Sea } & $\mathrm{TSP}=37.2$ & 1.857 & 0.80 & 2.53 & 6.42 & 26 \\
\hline & $\mathrm{PM}_{2.5}=18.7$ & 1.688 & 0.39 & 0.99 & 5.42 & \\
\hline \multicolumn{2}{|l|}{ La Esperanza, Maracaibo Lake Basin, Venezuela } & & & & & 19 \\
\hline Rainy season & $\mathrm{TSP}=25.6$ & 0.40 & 1.33 & 0.30 & 5.4 & \\
\hline Dry season & $\mathrm{TSP}=52.1$ & 0.67 & 7.04 & 0.38 & 4.0 & \\
\hline Seoul, Korea & $\mathrm{PM}_{2.5}=47.8$ & 5.89 & 2.95 & 9.26 & 5.99 & 27 \\
\hline \multicolumn{2}{|l|}{ Tainan coastal area, southern Taiwan } & & & & & 28 \\
\hline January & $\mathrm{PM}_{2.5}=62.4$ & 6.7 & 1.2 & 9.4 & 11.8 & \\
\hline April & $\mathrm{PM}_{2.5}=33.2$ & 6.5 & 0.7 & 2.0 & 4.1 & \\
\hline Taen (background), South Korea & $\mathrm{PM}_{2.5}=22.5$ & 1.71 & $<0.5$ & 0.79 & 5.63 & 29 \\
\hline \multicolumn{2}{|l|}{ Qingdao (coastal area), China } & & & & & 30 \\
\hline Summer & $\mathrm{PM}_{2.5}=47.9$ & 5.37 & 0.38 & 2.54 & 12.70 & \\
\hline Winter & $\mathrm{PM}_{2.5}^{2.5}=56.9$ & 8.13 & 1.31 & 9.04 & 16.10 & \\
\hline Agra (rural), India & $\mathrm{TSP}=131.6$ & 1.063 & 0.316 & 1.134 & 1.216 & 31 \\
\hline \multicolumn{2}{|l|}{ Milan, Italy } & & & & & 32 \\
\hline Cold season & $\mathrm{PM}_{2.5}=53.7$ & 5.2 & 0.6 & 20.2 & 5.8 & \\
\hline Warm season & $\mathrm{PM}_{2.5}^{2.5}=20.2$ & 2.2 & 0.09 & 4.6 & 4.0 & \\
\hline \multicolumn{2}{|l|}{ Veszprém, Hungary } & & & & & 33 \\
\hline Winter & $\mathrm{PM}<16 \mu \mathrm{m}=$ not given & 4.16 & 1.58 & 4.36 & 7.27 & \\
\hline Summer & $\mathrm{PM}<16 \mu \mathrm{m}=$ not given & 2.54 & 1.89 & 1.24 & 6.11 & \\
\hline
\end{tabular}

in the droplet mode. Alternatively, the heteromolecular nucleation of ammonia gas with some acidic gases can originate aerosols in the condensation mode. Sulphate and ammonium accounted, respectively, for $10-34$ and $1-16 \%$ by mass of the particulate matter. The foremost unimodal pattern of $\mathrm{SO}_{4}^{2-}$ and $\mathrm{NH}_{4}^{+}$peaking below 1 $\mu \mathrm{m}$ is consistent with the size distributions of these ions measured in California ${ }^{34}$, Veszprem, Hungary ${ }^{35}$, Agra, India ${ }^{31}$, three Korean urban sites ${ }^{27}$, Taipei ${ }^{36}$, Shanghai ${ }^{20}$, Pittsburgh ${ }^{37}$, Mexico City ${ }^{2}$, Adriatic coast of Slovenia ${ }^{38}$, Deuselbach, rural western Germany ${ }^{39}$, Hong Kong ${ }^{40}$, and Marseilles/Fos-Berre region ${ }^{22}$.

The mass fraction of nitrate in PM ranged between 5 and $20 \%$. The $\mathrm{NO}_{3}$-particles were concentrated in the coarse size. This size distribution is in accordance with previous observations in marine aerosols ${ }^{16,36,40}$. One of the proposed mechanisms to explain the presence of $\mathrm{NO}_{3}^{-}$in coarse particles is the reaction of $\mathrm{HNO}_{3}$ with soil particles contents such as calcium or magnesium carbonates ${ }^{40,41}$. Other than sea salt, soil particles, which are categorised in coarse mode, may absorb water and form droplets. The soil surface can then act as an absorbing solution. Aerosol $\mathrm{NO}_{3}^{-}$may thus be formed by the absorption and subsequent reaction of $\mathrm{NO}_{2}$ on the soil aerosol droplet or by dissolution of gaseous nitric acid ${ }^{31}$. When temperature is high and relative humidity is low, as it occurs in spring/summer in Portugal, the $\mathrm{NH}_{4} \mathrm{NO}_{3}$ equilibrium with nitric acid and ammonia favours the gas phase. Sequentially, neutralisation and scavenging from the gaseous phase of nitric acid by alkaline components of mineral and marine aerosols adds nitrate to coarse particles ${ }^{22,42}$. Significant higher levels of fine $\mathrm{NO}_{3}^{-}$were observed at a sub-urban area located in the north outskirts of Lisbon in autumn/winter. Those levels were attributed to the shifting of the $\mathrm{NH}_{4} \mathrm{NO}_{3(\mathrm{~s})} \leftrightarrow$ $\mathrm{NO}_{3(\mathrm{~g})}+\mathrm{NH}_{3(\mathrm{~g})}$ equilibrium to the aerosol phase, for the lower temperatures and higher relative humidities registered on these seasons ${ }^{42}$. Thus, in autumn/winter, regression analysis of $\mathrm{NO}_{3}{ }^{-}$versus $\mathrm{NH}_{4}^{+}$would result in higher correlation coefficients that those calculated for warmer periods.

The $\mathrm{Cl}^{-}$ion represented $2-20 \%$ of the particulate mass. As expected, it was present in relatively large amounts in the coarse fraction, owing to the influence of marine air masses and the proximity of the coast. Approximately $90 \%$ of its mass was found in the size range between 2 and $16 \mu \mathrm{m}$, which includes the characteristic mode for marine aerosols. Its concentration was up to 5 times higher during sampling times with an exclusive maritime influence than levels registered with continental air masses.

To better comprehend the origin of the particles and their constitution, the correlation coefficients between mass concentrations of water-soluble ions and $\mathrm{PM}$ were calculated (Table 2). $\mathrm{PM}, \mathrm{NH}_{4}^{+}$ and $\mathrm{SO}_{4}{ }^{2-}$ show reasonable correlations between each other. $\mathrm{A}$ moderate relationship between $\mathrm{SO}_{4}^{2-}$ and $\mathrm{NO}_{3}^{-}$was also observed, suggesting a common source. The somewhat high correlation coefficient between $\mathrm{SO}_{4}^{2-}$ and $\mathrm{NH}_{4}^{+}$indicates that $\left(\mathrm{NH}_{4}\right)_{2} \mathrm{SO}_{4}$ and/ or $\mathrm{NH}_{4} \mathrm{HSO}_{4}$ were present in PM. Probably, in the spring/summer period there is a $\mathrm{SO}_{4}^{2-}$ increase due to the stronger solar radiation, which speeds up the formation of $\mathrm{OH}$ radicals and promotes the formation of secondary sulphates ${ }^{42}$. The stability of the aerosol products resulting from the ammonia reaction with acidic gases 
Chloride, maritime air masses

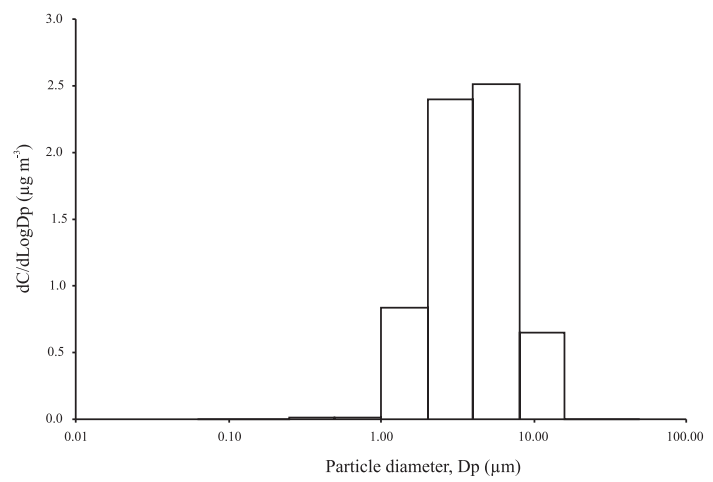

Ammonium, maritime air masses

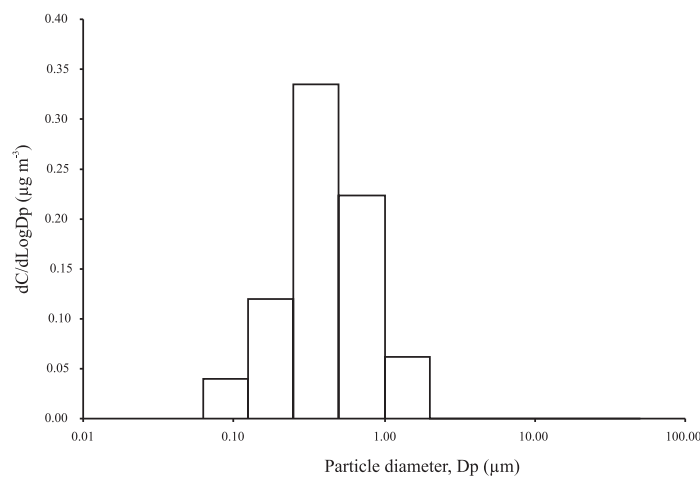

Sulphate, maritime air masses

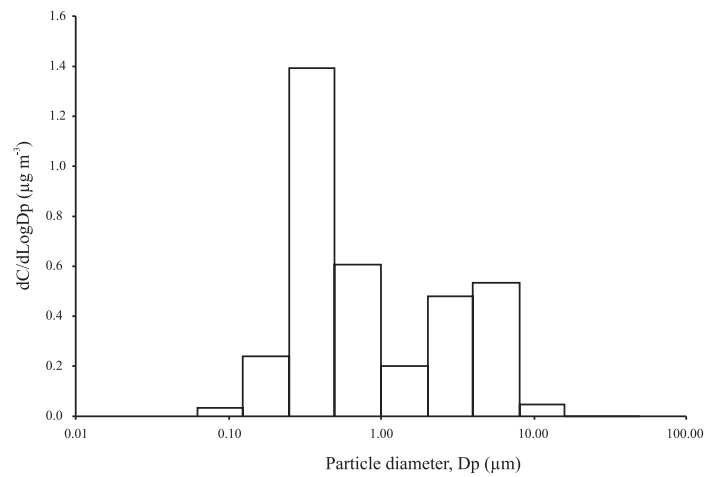

Nitrate, maritime air masses

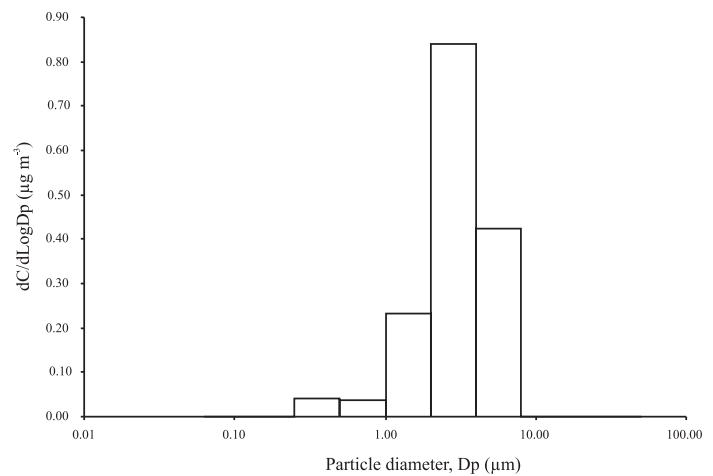

Chloride, continental air masses

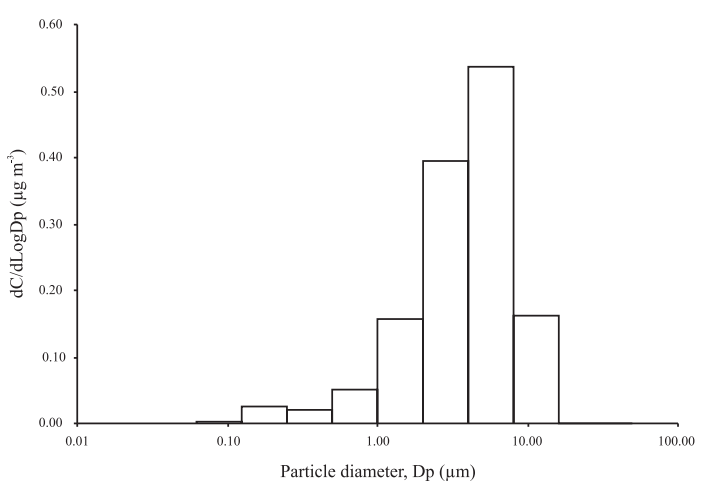

Ammonium, continental air masses

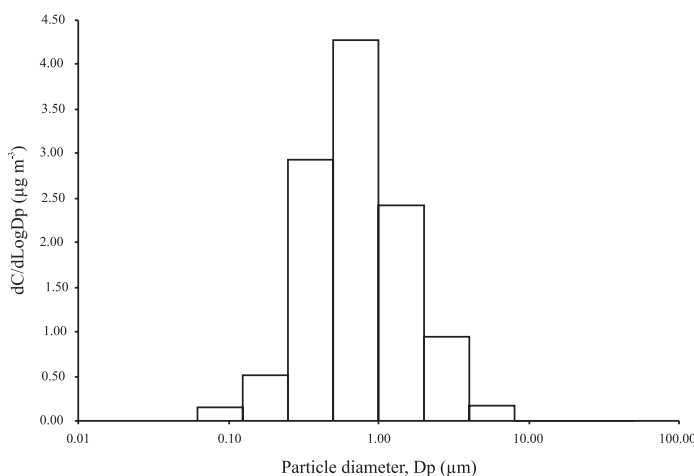

Sulphate, continental air masses

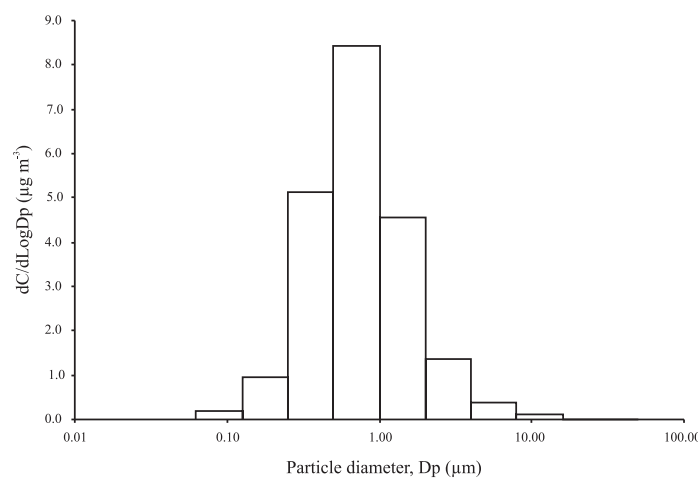

Nitrate, continental air masses

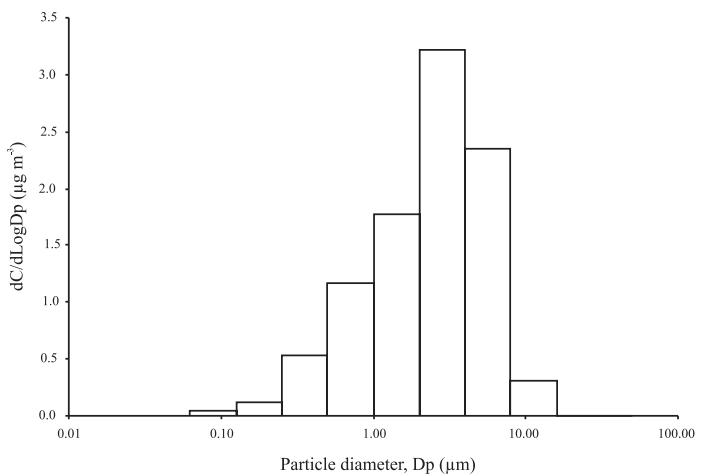

Figure 4. Mass size distributions of ionic species in atmospheric aerosols from Aveiro 
(e.g. sulphuric acid, nitric acid and hydrochloric acid) is different: ammonium sulphate is most stable while ammonium chloride is most volatile; hence ammonia prefers to react with sulphuric acid or sulphate ${ }^{40}$. This explains the higher positive relationship between $\mathrm{NH}_{4}^{+}$and $\mathrm{SO}_{4}^{2-}$ and the lower negative correlation between $\mathrm{NH}_{4}^{+}$ and $\mathrm{Cl}^{-}$.

Table 2. Spearman correlation coefficient between particulate species

\begin{tabular}{lccccc}
\hline & $\mathrm{PM}$ & $\mathrm{NH}_{4}^{+}$ & $\mathrm{Cl}^{-}$ & $\mathrm{NO}_{3}{ }^{-}$ & $\mathrm{SO}_{4}{ }^{2-}$ \\
\hline $\mathrm{PM}$ & 1.00 & & & & \\
$\mathrm{NH}_{4}^{+}$ & 0.75 & 1.00 & & & \\
$\mathrm{Cl}^{-}$ & -0.35 & -0.43 & 1.00 & & \\
$\mathrm{NO}_{3}^{-}$ & 0.50 & 0.59 & -0.18 & 1.00 & \\
$\mathrm{SO}_{4}^{2-}$ & 0.85 & 0.74 & -0.44 & 0.66 & 1.00 \\
\hline
\end{tabular}

The mass ratio of $\left[\mathrm{NO}_{3}^{-}\right] /\left[\mathrm{SO}_{4}{ }^{2-}\right]$ has been used as an indicator of the relative importance of stationary versus mobile sources of sulphur and nitrogen in the atmosphere ${ }^{23}$. In Guiyang, a region of SW China where the coal burned has $1.86 \%$ of sulphur, this mass ratio in TSP ranged between 0.01 and 0.38 (average 0.13 ), and much lower than the range (0.3-0.5) reported for Chinese traffic stations $^{23}$. In Aveiro, the ratio presented values in the interval 0.030.16 (average 0.06 ), suggesting that stationary source emissions were more important than the vehicle emissions. It should be noted, however, that previous measurements in the Aveiro region revealed $\mathrm{SO}_{2}$ concentrations somewhat higher than at other marine sites in the North Atlantic, reflecting the importance of natural sulphur emissions (e.g. DMS) in coastal waters or air mass contamination induced by mesoscale wind circulation. It was also verified that DMS concentrations rise during the warmer months ${ }^{16}$. On the other hand, the ratio of $\left[\mathrm{NO}_{3}^{-}\right] /\left[\mathrm{SO}_{4}^{2-}\right]$ is expected to be lower in the spring/ summer period, because ammonium nitrate volatilises at higher air temperature, and thus lowering the ratio ${ }^{23}$.

The ammonium salts, mostly of secondary formation, outcome from the following processes ${ }^{32}$ : ammonia is first depleted by reaction with $\mathrm{H}_{2} \mathrm{SO}_{4}$ to form $\left(\mathrm{NH}_{4}\right)_{2} \mathrm{SO}_{4}$ and the remaining free ammonia is depleted by reaction with $\mathrm{HNO}_{3}$ to form $\mathrm{NH}_{4} \mathrm{NO}_{3}$. Therefore, in $\mathrm{NH}_{3}$-limited areas, $\mathrm{HNO}_{3}$ cannot be fully neutralised by ammonia to form fine particles of ammonium nitrate, but reacts with coarse alkaline soil particles to form coarse particles. According to theory, if the total ammonium/total sulphate molar ratio is $<2$, then the regime is defined as ammonia-poor environment. On the contrary, if the ratio is $>2$, then the system is classified as ammonia-rich environment. Specifically, if the $\mathrm{NH}_{4}^{+} / \mathrm{SO}_{4}{ }^{2-}$ ratio is ${ }^{2}: \leq 0.5$, the aerosol particles exist primarily as $\mathrm{H}_{2} \mathrm{SO}_{4}$ solutions; between $0.5-$ $1.25, \mathrm{NH}_{4} \mathrm{HSO}_{4(\mathrm{~s})}$ (or an $\mathrm{NH}_{4}^{+}$and $\mathrm{HSO}_{4}^{-}$solution) is the dominant component of the system; between 1.25-1.5, $\mathrm{NH}_{4} \mathrm{HSO}_{4(\mathrm{~s})}$ and $\left(\mathrm{NH}_{4}\right)_{3} \mathrm{H}\left(\mathrm{SO}_{4}\right)_{2}$ (letovicite), or a solution with the corresponding ions, coexist in the system; equal to 1.5 , the aerosol phase consists exclusively of letovicite (or a solution with the corresponding ions); equal to 2, all the ammonia is fully neutralized with the sulphate present, and therefore, the predominant component in the system is $\left(\mathrm{NH}_{4}\right)_{2} \mathrm{SO}_{4(\mathrm{~s})}$ or a solution with the corresponding ions.

During some spring/summer events, in the Aveiro area, an ammonium surplus was observed, perhaps due to greater availability of ammonia in this period, coming from agricultural activities neighbouring the urban area or from the chemical industrial complex of Estarreja. Thus, $\mathrm{NH}_{4}{ }^{+} / \mathrm{SO}_{4}^{2-}$ molar ratios $>2$ were gotten in the beginning of April, end of May and during the last week of August. During the remaining periods, the ratio was between 0.5 and 1.25 , which means that aerosol was somewhat acidic and predominantly in the form of $\mathrm{NH}_{4} \mathrm{HSO}_{4(\mathrm{~s})}$. The sum of $\mathrm{SO}_{4}{ }^{2-}$ and $\mathrm{NO}_{3}^{-}$was moderately correlated with $\mathrm{NH}_{4}^{+}(\mathrm{r}=0.60)$ with a slope of regression larger than 1 , indicating an incompletely neutralised system ${ }^{41}$. Low contents of $\mathrm{Cl}^{-}$found in the aerosol samples reinforce this assessment, as in the presence of an acidic aerosol, $\mathrm{Cl}^{-}$escapes the particulate phase as gaseous $\mathrm{HCl}^{22}$. However, these conclusions should be taken with some precaution, since the coarse nitrate particles could be products of the reactions between nitric acid and sea salts or some other mineral particles. Thus, the $\mathrm{NO}_{3}^{-}$could be neutralised by sea salt and mineral components (e.g., $\mathrm{Na}^{+}$and $\mathrm{Ca}^{2+}$ ). The measurement of additional species would have been necessary to draw definitive conclusions.

\section{CONCLUSIONS}

Sulphate, nitrate, chloride and ammonium represented, on average, $20.8,10.1,5.4$ and $4.1 \%$ of the particulate mass, respectively. Sulphate and ammonium were the prevailing species in fine particles. The droplet mode dominated the distributions of these two ions. Continental air masses increased their fine mode concentrations. This augment was mainly due to sulphate accumulation from the aqueous reactions in fog and cloud droplets, which then remained as droplet mode particles as water evaporated. An enhancement of $\mathrm{SO}_{4}^{2-}$ levels corresponding to the coarse sizes was registered simultaneously with a strong maritime influence of air masses, due to a likely contribution from sea-salt. Nitrate dominantly existed in the coarse mode. It was associated to neutralisation and scavenging from the gaseous phase of nitric acid by alkaline components of mineral and marine aerosols. Similar size distribution characteristics were found for chloride. It was verified a clear augmentation in its concentrations and an enrichment of the coarse fraction with a concomitant predominance of air masses from the ocean. The sum of $\mathrm{SO}_{4}{ }^{2-}$ and $\mathrm{NO}_{3}{ }^{-}$was moderately correlated with $\mathrm{NH}_{4}^{+}$with a slope of regression larger than 1 , indicating a likely incompletely neutralised system. Excepting some ammonia-rich events, aerosols were acidic $\left(\mathrm{NH}_{4}{ }^{+} / \mathrm{SO}_{4}{ }^{2-}\right.$ molar ratio less than 2), which is potentially important in assessing heath effects of airborne particles.

\section{SUPPLEMENTARY INFORMATION}

Additional information concerning the sampling location and the typical synoptic-scale low pressure systems is available free of charge at http://quimicanova.sbq.org.br, as a PDF file.

\section{ACKNOWLEDGMENTS}

We would like to thank Mr. F. Oliveira for providing meteorological data and Prof. M. Cerqueira for his precious advices on analytical procedures.

\section{REFERENCES}

1. Seinfeld, J. H.; Pandis, S. N.; Atmospheric chemistry and physics: from air pollution to climate changes, John Wiley \& Sons: New York, 1998.

2. Moya, M.; Castro, T.; Zepeda, M.; Baez, A.; Atmos. Environ. 2003, 37, 3581 .

3. Charlson, R. J.; Schwartz, S. E.; Hales, J. M.; Cess, R. D.; Coakley, J. A.; Hansen, J. E.; Hofmann, D. J.; Science 1992, 255, 423.

4. Haywood, J. M.; Ramaswamy, V.; Donner, L. J.; Geophys. Res. Lett. 1997, $24,143$.

5. Penner, J. E.; Chuang, C. C.; Grant, K.; Clim. Dynam. 1998, 14, 839.

6. Haywood, J. M.; Boucher, O.; Rev. Geophys. 2000, 38, 513.

7. Adams, P. J.; Seinfeld, J. H.; Koch, D. M.; Mickley, L.; Jacob, D.; J. Geophys. Res. 2001, 106, 1097. 
8. Jacobson, M. Z.; J. Geophys. Res. 2001, 106, 1551.

9. Rosenfield, J. E.; Cosidine, D. B.; Meade, P. E.; Bacmeister, J. T.; Jackman, C. H.; Schoeberl, M. R.; J. Geophys. Res. 1997, 102, 3649.

10. Sutton, M. A.; Dragositis, U.; Tang, Y. S.; Fowler, D.; Atmos. Environ. 2000, 34,855 .

11. Marley, N. A.; Gaffney, J. J.; Sixth Conference on Atmospheric Chemistry: Air Quality in Megacities; Seattle, Washington, 2004.

12. Adams, P. J.; Sienfeld, J. H.; Koch, D.; J. Geophys. Res. 1999, 104, 13791.

13. Asman, W. A.; Nova Acta Leopold. 1994, 70, 263.

14. Cass, G. In Ozone, Particulate Matter, Regional Haze; Federal Advisory Committee Act, ed.; U.S. Environmental Protection Agency, 1997.

15. Dorland, R.; Dentener, F. J.; Lelieveld, J.; J. Geophys. Res. 1997, 102, 28079 .

16. Pio, C. A.; Cerqueira, M. A.; Castro, L. M.; Salgueiro, M. L.; Atmos. Environ. 1996, 30, 3115

17. Weatherburn, M. W.; Anal. Chem. 1967, 39, 971.

18. Dingenen, R.; Raes, F.; Putaud J.-P.; Baltensperger, U.; Charron, A.; Facchini, M. C.; Decesari, S.; Fuzzi, S.; Gehrig, R.; Hansson, H.-C.; Harrison, R. M.; Hüglin, C.; Jones, A. M.; Laj, P.; Lorbeer, G.; Maenhaut, W.; Palmgren, F.; Querol, X.; Rodriguez, S.; Schneider, J.; Brink, H.; Tunved, P.; Tørseth, K.; Wehner, B.; Weingartner, E.; Wiedensohler, A.; Wåhlin, P.; Atmos. Environ. 2004, 38, 2561.

19. Morales, J. A.; Pirela, D.; Nava, M. G.; Borrego, B. S.; Velásquez, H.; Durán, J.; Atmos. Res. 1998, 46, 307.

20. Wang, Y.; Zhuang, G.; Zhang, X.; Huang, K.; Xu, C.; Tang, A.; Chen, J.; An, Z.; Atmos. Environ. 2006, 40, 2935.

21. Takami, A.; Miyoshi, T.; Shimono, A.; Hatakeyama, S.; Atmos. Environ. 2005, 39, 4913.

22. Cachier, H.; Aulagnier, F.; Sarda, R.; Gautier, F.; Masclet, P.; Besombes, J. L.; Marchand, N.; Despiau, S.; Croci, D.; Mallet, M.; Laj, P.; Marinoni, A.; Deveau, P. A.; Roger, J. C.; Putaud, J. P.; Dingenen, R.; Dell'Acqua, A.; Viidanoja, J.; Santos, S. M.; Liousse, C.; Cousin, F.; Rosset, R.; Gardrat, E.; Galy-Lacaux, C.; Atmos. Res. 2005, 74, 547.
23. Xiao, H.-Y.; Liu, C.-Q.; Atmos. Environ. 2004, 37, 6297.

24. Hien, P. D.; Bac, V. T.; Thinh, N. T. H.; Atmos. Environ. 2005, 39, 7231

25. Lin, J. J.; Atmos. Environ. 2002, 36, 1911.

26. Lee, S.-B.; Bae, G.-N.; Moon, K.-C.; Kim, Y. P.; Atmos. Environ. 2002, $36,5427$.

27. Park, S. S.; Kim, Y. J.; Atmos. Environ. 2004, 38, 1459.

28. Tsai, Y. I.; Kuo, S.-C.; Atmos. Environ. 2005, 39, 4827.

29. Kim, K.-H.; Choi, G.-H.; Kang, C.-H.; Lee, J.-H.; Kim, J. Y.; Youn, Y. H.; Lee, S. R.; Atmos. Environ. 2003, 37, 753.

30. Hu, M.; He, L.-Y.; Zhang, Y.-H.; Wang, M.; Kim, Y. P.; Moon, K. C.; Atmos. Environ. 2002, 36, 5853.

31. Parmar, R. S.; Satsangi, G. S.; Kumari, M.; Lakhani, A.; Srivastav, S. S.; Prakash, S.; Atmos. Environ. 2001, 35, 693.

32. Lonati, G.; Giugliano, M.; Butelli, P.; Romele, L.; Tardivo, R.; Atmos. Environ. 2005, 39, 1925.

33. Krivácsy, Z.; Molnár, Á.; Atmos. Res. 1998, 46, 279.

34. Hering, S.; Eldering, A.; Seinfeld, J.; Atmos. Environ. 1997, 31, 1

35. Meszaros, E.; Barcza, T.; Gelencser, A.; Labia, J.; Kiss, G.; Krivacsy, Z.; Molnar, A.; Polyak, K.; J. Aerosol Sci. 1997, 28, 1163.

36. Chou, C. C.-K.; Huang, S.-H.; Chen, T.-K.; Lin, C.-Y.; Wang, L.-C.; Atmos. Res. 2005, 75, 89.

37. Cabada, J. C.; Rees, S.; Takahama, S.; Khlystov, A.; Pandis, S. N.; Davidson, C. I.; Robinson, A. L.; Atmos. Environ. 2004, 38, 3127.

38. Turši, J.; Podkrajšek, B.; Grgi, I.; Ctyroky, P.; Berner, A.; Dusek, U.; Hitzenberger, R.; Chemosphere 2006, 63, 1193.

39. Mehlmann, A.; Warneck, P.; Atmos. Environ. 1995, 29, 2359.

40. Zhuang, H.; Chan, C. K.; Fang, M.; Wexler, A. S.; Atmos. Environ. 1999, 33,843

41. Yao, X.; Chan, C. K.; Fang, M.; Cadle, S.; Chan, T.; Mulawa, P.; He, K.; Ye, B.; Atmos. Environ. 2002, 36, 4223.

42. Almeida, S. M.; Pio, C. A.; Freitas, M. C.; Reis, M. A.; Trancoso, M. A.; Atmos. Environ. 2005, 39, 3127. 
Célia Alves*, Casimiro Pio, Eduarda Campos and Patrícia Barbedo

Departamento de Ambiente e Ordenamento, Centro de Estudos do Ambiente e do Mar, Universidade de Aveiro,

Campus de Santiago, 3810-193 Aveiro, Portugal

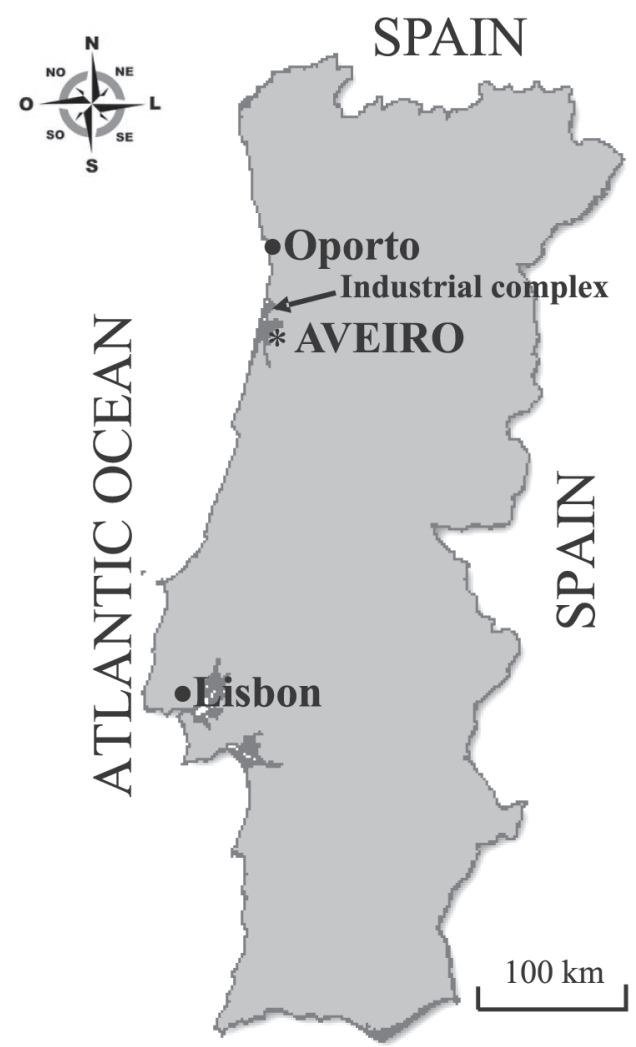

Figure S1. Map of Portugal showing the location of the sampling site, AVEIRO

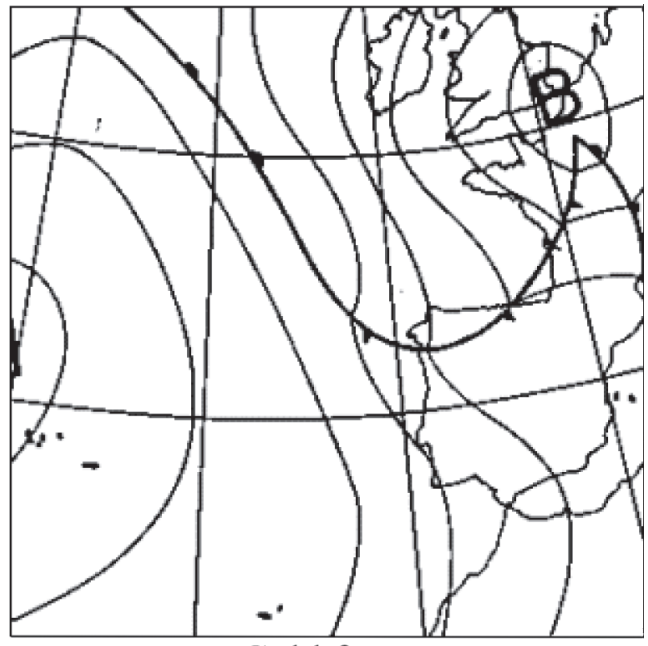

Cold front

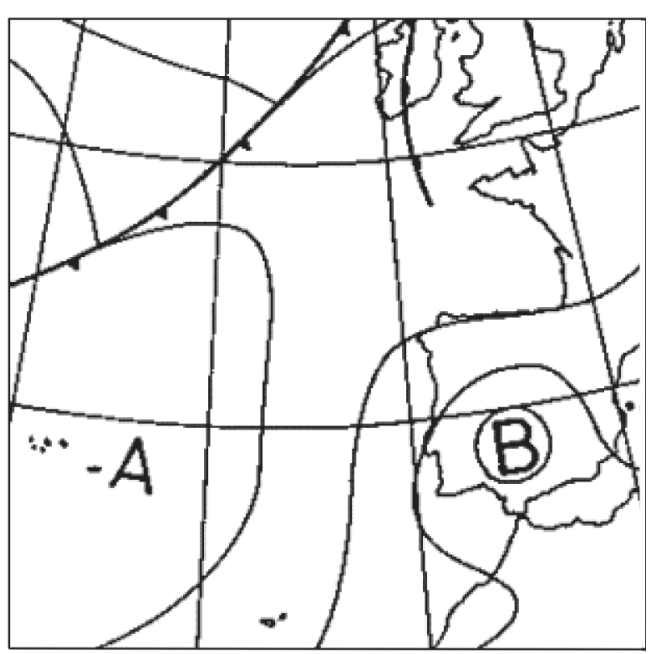

Thermal low pressure 